\title{
Association of Olpidium bornovanus and Melon necrotic spot virus with Vine Decline of Melon in Guatemala
}

\author{
M. de Cara and V. López, Dpto. Producción Vegetal, Universidad de Almería, 04120, Spain; M. C. Córdoba, Dpto. \\ Ecosistemas Agroforestales, Universidad Politécnica de Valencia, Spain; M. Santos, Dpto. Producción Vegetal, Uni- \\ versidad de Almería; C. Jordá, Dpto. Ecosistemas Agroforestales, Universidad Politécnica de Valencia; and J. C. Tello, \\ Dpto. Producción Vegetal, Universidad de Almería
}

\begin{abstract}
de Cara, M., López, V., Córdoba, M. C., Santos, M., Jordá, C., and Tello, J. C. 2008. Association of Olpidium bornovanus and Melon necrotic spot virus with vine decline of melon in Guatemala. Plant Dis. 92:709-713.

Thirty-one soil samples from 14 different fields of Guatemala melon with vine decline symptoms were analyzed for the presence of organisms associated with the disease. With a soildilution plating method, only Macrophomina phaseolina was detected in five samples. With a melon bait plant technique, Olpidium bornovanus, often together with Melon necrotic spot virus (MNSV), was found in nearly all the samples, corresponding with all the fields studied. Other pathogens that were detected less frequently included Pythium aphanidermatum, Monosporascus cannonballus, and Rhizoctonia solani. Consequently, O. bornovanus and MNSV were uniquely associated with disease occurrence and thus are the most probable cause of melon vine decline in the fields studied.
\end{abstract}

Additional keywords: Acremonium, collapse, soil phytopathometry, sudden wilt

Approximately 9,000 ha of muskmelon, mainly cantaloupe and honeydew types, are grown annually in Guatemala, mostly for export to the United States. With coffee and tobacco, melon is the most important crop in the province of Zacapa in Guatemala. Traditionally, three 60-day cycles of melon are grown annually, beginning in September and ending in April. Each year, farmers disinfest the soils with methyl bromide or other chemicals to control soilborne diseases and weeds. In recent years, the most important soilborne disease in melon is a vine decline disease (VD), whose symptoms are canopy collapse or sudden wilt of plants. Presence of the disease has forced farmers to grow only two crops per year and to disinfest soils before each crop, rather than using one application prior to the first crop. Losses due to collapse of melon reach 5 to $10 \%$ of plants in the first crop and more than $50 \%$ in the second crop. The third crop results are unfeasible. General disease symptoms are wilting, subsequently followed by death of plants. The symptoms appear during harvesting or days before $(8,15)$. The syndrome has been described from melongrowing areas worldwide, and may be

Corresponding author: M. de Cara

E-mail: mdecara@ual.es

Accepted for publication 3 December 2007.

doi:10.1094/PDIS-92-5-0709

(C) 2008 The American Phytopathological Society caused by a complex of different pathogens $(4,24)$. Causal agents of VDs of melon include primarily Monosporascus cannonballus Pollack \& Uecker (35) and M. eutypoides (Petr.) Arx (29), which are considered conspecific by Lovic et al. (22), Macrophomina phaseolina (Tassi) Goid. (5), Acremonium cucurbitacearum AlfaroGarcia, W. Gams \& Garcia-Jim. (13), Rhizopycnis vagum D.F. Farr $(12,26)$, Melon necrotic spot virus (MNSV) when associated with Olpidium bornovanus (Sahtiy.) Karling (syn.: O. radicale Swartz \& Ivimey Cook and O. cucurbitacearum D.J.S. Barr \& Dias) $(8,34)$, Pythium ultimum Trow, $P$. aphanidermatum (Edson) Fitzp. (16,17), and Fusarium solani (Mart.) Sacc. f. sp. cucurbitae (7). Rhizoctonia solani Kühn also has been reported as a causal agent of sudden wilt of melon in Spain (6) and Israel (28).

Diagnosis of the disease requires the detection and identification of the causal agents. P. ultimum, P. aphanidermatum, A. cucurbitacearum, Rhizopycnis vagum, and M. phaseolina can be easily isolated from roots or crown on agar media $(1,14)$. Monosporascus spp. are difficult to isolate from roots of symptomatic plants but the perithecia visible on infected roots are readily identified under a microscope $(24,25)$. To detect $O$. bornovanus, it is necessary to examine the feeder roots under a light microscope because, as an obligate intracellular pathogen, it cannot be cultivated on synthetic media $(14,30)$. It is nearly impossible to obtain feeder roots from field-diseased plants. Infection of plants with MNSV can be established using serological or polymerase chain reaction (PCR) techniques on the stem tissue below the cotyledons of infected plants (8).

The objective of this study was to determine the presence of different fungi implicated in the collapse of melon in Guatemala through the analysis of infested soils by two different techniques.

\section{MATERIALS AND METHODS}

Soil sampling and preparation of samples. Soil samples were collected from 31 soils belonging to 14 different fields in the province of Zacapa, Guatemala. When symptoms of collapse were observed close to harvest of the first-season crop, 10 soil samples taken with a $15-\mathrm{cm}$ probe to a depth of $25 \mathrm{~cm}$ from the root zone were randomly collected from each field, pooled, and thoroughly mixed. The resulting composite sample weighed approximately $1 \mathrm{~kg}$. In the laboratory, each sample was put into a tray and covered with a filter paper to avoid airborne contaminations and air dried for 2 to 3 weeks. After screening through a $200-\mu \mathrm{m}$ sieve, the fine fraction was used for dilution plating on acidified malt-extract agar ( $\mathrm{pH}=4.0)(33)$. The coarse fraction was used to bait the fungi from soils using melon plants $(9,14)$.

Isolation directly from soils. A soildilution plate technique was used to isolate nonobligate pathogens that cause collapse of melon, such as A. cucurbitacearum, $M$. phaseolina, $R$. vagum, and Rhizoctonia solani, from the fine soil fraction (particle size less than $200 \mu \mathrm{m}$ each sample) (33). A 10 -g subsample was suspended in sterile water at 1 in $10^{2}, 1$ in $10^{3}$, and 1 in $10^{4}$ (wt:wt). After the suspensions were homogenized by hand shaking for $4 \mathrm{~min}, 1$ $\mathrm{ml}$ of suspension was transferred to each of 10 sterile petri dishes; then, acidified malt-extract agar (Difco Laboratories, Detroit) at $10 \mathrm{ml}$ per dish was added to each plate. The medium had been autoclaved previously $\left(121^{\circ} \mathrm{C}, 30 \mathrm{~min}\right)$ and left to cool to 32 to $35^{\circ} \mathrm{C}$. Petri dishes were incubated at room temperature and examined for fungi after 2, 5, 10, and 15 days. Plates containing less than $100 \mathrm{CFU}$ were used for fungal population analysis. Morphological criteria were used to identify the different fungal colonies $(2,18,19$, 27,36). Results are expressed as CFU per gram of soil. 
Isolation with bait plants. Pathogens were baited from soil by growing melon plants for 45 days in a 1:6 (wt:wt) mixture of field soil:vermiculite. The vermiculite had been sterilized by autoclaving at $121^{\circ} \mathrm{C}$ for $60 \mathrm{~min}$. The soil:vermiculite dilution was sufficient to avoid early damping off by Pythium spp. or $R$. solani (9).

The analysis with bait plants had six replicates per each of the 31 soil samples. Each replicate consisted of $25 \mathrm{~g}$ dry weight of soil mixed separately with $150 \mathrm{~g}$ of autoclaved vermiculite and added to 1-liter plastic glasses. Four 1-cm-diameter holes were made at $5 \mathrm{~cm}$ from the base of the glass. This was done to preserve moisture in the glass but avoid flooding. Seed of the susceptible muskmelon cv. AmarilloCanario (Ramiro Arnedo, Spain) were disinfested for $10 \mathrm{~min}$ in a $10 \%$ trisodium phosphate solution (Panreac Momplet and Esteban S.A., Spain), germinated in a moist chamber for 3 to 4 days, and then sown in the glasses (6 seeds/pot). The glasses were distributed randomly in a climatic chamber $\left(23\right.$ and $29^{\circ} \mathrm{C}, 16 \mathrm{~h}$ of fluorescent radiation at $12 \times 10^{3} \mathrm{lux} / \mathrm{day}$ ), and plants were hand watered each 2 or 3 days with tap water and supplied with a complex fertilizer (Hakaphos Verde; BASF, Germany). After 45 days (the time necessary to make sure that all the fungal pathogens had an opportunity to colonize the roots and the MNSV was detectable on stems below cotyledons), the surviving melon plants were carefully removed from the pots and the roots washed free of soil and vermiculite. The roots then were analyzed depending on the pathogen (see below). Plants that died before 45 days were analyzed for nonobligate pathogens at the time of plant death. Two bait plant analyses were done for those soil samples with enough soil available after the first bait plant analysis. Those soils were stored in sterile jars of glass at environmental conditions. This second analysis was started just when the first one was ended. Negative controls consisted of pots filled with $175 \mathrm{~g}$ of sterile vermiculite. A positive control for Acremonium spp. (a soil with a known

Table 1. Incidence of Olpidium bornovanus and Melon necrotic spot virus (MNSV) in roots of muskmelon grown in soil from melon production fields in Guatemala under controlled environmental conditions $^{\mathrm{a}}$

\begin{tabular}{|c|c|c|c|c|}
\hline \multirow[b]{2}{*}{ Sample ${ }^{b}$} & \multicolumn{2}{|c|}{ First assay } & \multicolumn{2}{|c|}{ Second assay } \\
\hline & O. bornovanus & MNSV & O. bornovanus & MNSV \\
\hline 1 & $5 / 5$ & $0 / 5$ & $6 / 6$ & $6 / 6$ \\
\hline 2 & $5 / 6$ & $1 / 6$ & $6 / 6$ & $6 / 6$ \\
\hline 3 & $2 / 2$ & $2 / 2$ & & \\
\hline 4 & $2 / 2$ & $1 / 2$ & $6 / 6$ & $5 / 6$ \\
\hline 5 & $6 / 6$ & $3 / 6$ & $3 / 6$ & $3 / 6$ \\
\hline 6 & $5 / 6$ & $1 / 6$ & $\ldots$ & $\ldots$ \\
\hline 7 & $3 / 3$ & $1 / 3$ & $\ldots$ & $\ldots$ \\
\hline 8 & $6 / 6$ & $2 / 6$ & $6 / 6$ & $1 / 6$ \\
\hline 9 & $3 / 3$ & $0 / 3$ & $6 / 6$ & $6 / 6$ \\
\hline $10^{\mathrm{I}}$ & $3 / 4$ & $4 / 4$ & $\ldots$ & $\ldots$ \\
\hline 11 & $1 / 1$ & $1 / 1$ & $\ldots$ & $\ldots$ \\
\hline $12^{\mathrm{I}}$ & $6 / 6$ & $1 / 6$ & $\ldots$ & $\ldots$ \\
\hline $13^{\mathrm{I}}$ & $1 / 3$ & $2 / 3$ & $\ldots$ & $\ldots$ \\
\hline $14^{\mathrm{I}}$ & $3 / 3$ & $0 / 3$ & $1 / 2$ & $2 / 2$ \\
\hline $15^{\mathrm{II}}$ & $3 / 3$ & $2 / 3$ & $\ldots$ & $\ldots$ \\
\hline $16^{\mathrm{II}}$ & $5 / 6$ & $1 / 6$ & $\ldots$ & $\ldots$ \\
\hline $17^{\mathrm{II}}$ & $4 / 6$ & $0 / 6$ & $0 / 6$ & $0 / 6$ \\
\hline $18^{\mathrm{II}}$ & $1 / 6$ & $0 / 6$ & $1 / 6$ & $0 / 6$ \\
\hline $19^{\mathrm{II}}$ & $1 / 6$ & $0 / 6$ & $6 / 6$ & $0 / 6$ \\
\hline $20^{\Pi I}$ & $3 / 6$ & $1 / 6$ & $\ldots$ & $\ldots$ \\
\hline $21^{\mathrm{II}}$ & $6 / 6$ & $0 / 6$ & 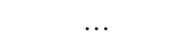 & $\ldots$ \\
\hline $22^{\mathrm{II}}$ & $1 / 1$ & $1 / 1$ & $5 / 5$ & $5 / 5$ \\
\hline $23^{\mathrm{II}}$ & $4 / 4$ & $2 / 4$ & $\ldots$ & $\ldots$ \\
\hline $24^{\mathrm{II}}$ & $0 / 6$ & $0 / 6$ & $\ldots$ & $\ldots$ \\
\hline $25^{\mathrm{II}}$ & $2 / 2$ & $0 / 2$ & $\ldots$ & $\ldots$ \\
\hline $26^{\mathrm{II}}$ & $4 / 5$ & $0 / 5$ & $\ldots$ & $\ldots$ \\
\hline 27 & $6 / 6$ & $2 / 6$ & $\ldots$ & $\ldots$ \\
\hline $28^{\mathrm{III}}$ & $6 / 6$ & $5 / 6$ & $\ldots$ & $\ldots$ \\
\hline $29^{\text {IIII }}$ & $4 / 6$ & $5 / 6$ & $\ldots$ & $\ldots$ \\
\hline $30^{\mathrm{III}}$ & $6 / 6$ & $5 / 6$ & $\ldots$ & $\ldots$ \\
\hline $31^{\mathrm{III}}$ & $5 / 6$ & $6 / 6$ & $\ldots$ & $\ldots$ \\
\hline Control & $0 / 26$ & $2 / 26$ & $0 / 12$ & $2 / 12$ \\
\hline
\end{tabular}

${ }^{a}$ Soil from each sample was diluted 1:6 with sterile vermiculite and added to a 1-liter plastic cup, where 6 seeds of the susceptible muskmelon cv. Amarillo-Canario (Ramiro Arnedo, Spain) were sown. Six replicates (glasses) per sample were distributed randomly in a climatic chamber (23 and $29^{\circ} \mathrm{C}, 16 \mathrm{~h}$ of fluorescent radiation at $12 \times 10^{3}$ lux/day) for 45 days. Roots of these plants were analyzed for $O$. bornovanus and a mixture of crown and roots for MNSV; data shown are replications with the pathogen/total number of replications.

${ }^{\mathrm{b}}$ Samples with the same superscript (I, II, and III) were taken from the same field. Otherwise, each sample represents a single field. history of Acremonium spp. from Murcia, Spain) was included.

Analysis for $O$. bornovanus. A $5-\mathrm{g}$ sample from the roots of the 45-day-old plants was collected randomly from the roots of each replication. The samples were submerged in a $1.5 \% \mathrm{KOH}$ (Panreac, Momplet and Esteban S.A.) solution for 24 $\mathrm{h}$ to clear the root surface, then examined under a light microscope to detect resting spores or sporangia of $O$. bornovanus. In all, 242 roots tangles corresponding with each "surviving" replicate were examined, 169 in the first assay and 73 in the second. Results were recorded as the number of positive roots tangles (replications) per total number of examined roots tangles.

Analysis for MNSV. Double-antibody sandwich enzyme-linked immunosorbent assay (DAS-ELISA) serological analyzes were carried out with a specific MNSV polyclonal antisera (Bio-Rad, Life Sciences, Barcelona, Spain). From each pot, a mixture of all the crowns and roots was extracted with a 1:10 (p/v) buffer (1x PBST, pH $7.4+2 \%$ PVP). Positive and negative controls were provided by BioRad. Two replicates were analyzed by ELISA. Tests were considered positive when the absorbance value was double the negative control. Optical density at $405 \mathrm{~nm}$ data where obtained with an ELISA Multiskan EX Model no. 355 reader, using Ascent Software v2.6 (Termo Electron Corporation). Ambiguous results were repeated and analyzed by one-step reversetranscription polymerase chain reaction (RT-PCR). ARN extractions were done from $0.1 \mathrm{~g}$ of roots. RNAwiz (Ambion Inc., Huntingdon, United Kingdom) was used. Tissue was ground with liquid $\mathrm{N}_{2}$. SuperScript One Step IIRT/Platinum Taq Mix (Invitrogen Life Technologies, Barcelona, Spain) was used. Samples were amplified with two specific MNSV coat protein primers (about 651 bp). A Mastercycler personal 5332 Eppendorf v1.3 (Eppendorf North America, Inc.) was used. RT-PCR products were purified with the High Pure PCR Purification Kit (Roche Diagnostics, Manheim, Germany), and resultant sequences compared, using a BLAST Program, with GenBank MNSV accession no. DQ443545.

Analysis for Monosporascus cannonballus. The root system of each plant was examined under a dissecting scope (at $\times 10$ ). When perithecia were observed, the species was identified by morphology and number of ascospores per asci as seen under higher $(\times 100)$ magnification (19).

Analysis for nonobligated pathogens. For each plant (36 plants per sample and bait plant analysis were analyzed), three rinsed and air-dried root pieces of $1 \mathrm{~cm}$, showing browning, were placed on acidified malt-extract agar plates. The plates were examined after 2, 5, 10, and 15 days. This analysis allowed us to detect Fusarium spp., Pythium spp., Acremonium spp., 
R. solani, Macrophomina phaseolina, and other fungi not associated with collapse of melon. The frequency of isolation of each fungus per sample was recorded. In all, 1,740 bait plants were analyzed (228 of these plants belonging to controls).

\section{RESULTS}

Isolation directly from soils. In general, analyzed soils yielded a relatively wide variety of fungi despite the fact that the soils were disinfested annually. Fungi belonging to 17 genera were isolated. Yeasts were found in two samples and identified as Candida spp. Pythium spp., $R$. solani, Monosporascus cannonballus, Acremonium spp., or Rhizopycnis vagum were not detected from soils. Only one of the reported causal agents of VD was detected: Macrophomina phaseolina, from five soils, corresponding to four fields. Fusarium roseum (sensu Messiaen \& Cassini), Penicillium spp., Paecilomyces spp., Aspergillus spp., Curvularia spp., F. oxysporum, and Rhizopus spp. were most prevalent, occurring in more than $50 \%$ of the samples.

Isolation with bait plants. Resting spores and sporangia of $O$. bornovanus were observed in roots from bait melon plants grown in 30 of the 31 samples, representing all the studied fields. In 18 samples, this chytridiomycete was present in all of their replicates (Table 1). MNSV was detected from 23 samples representing all the studied fields and always co-occurring with $O$. bornovanus. Only controls with vermiculite were positive for MNSV in $10.5 \%$, but never $O$. bornovanus (Table 1 ). Resultant PCR sequences confirmed the similarity with Gen Bank MNSV sequences.

Only three samples, belonging to the same field, tested positive for perithecia of Monosporascus cannonballus. This fungus was isolated by plating root pieces from one of these samples. Fungi of 17 different genera were isolated from roots of bait plants when plated on acidified maltextract agar medium (Table 2). Neither $A$. cucurbitacearum nor $R$. vagum were isolated from the 4,356 root pieces, while the Acremonium sp. was isolated in $33.3 \%$ of the plants grown in the positive control for Acremonium using the bait plants. From known fungi associated with collapsed melon plants, $F$. solani was most frequently isolated; however, the high frequency occurrence of this species in the controls complicates the interpretation of this result. Moreover, pathogenicity, as a VD pathogen, of this fungus could not be proved on melon (7). P. aphanidermatum was the pathogen most frequently isolated by root plating, being isolated from 20 samples representing 11 of 14 studied fields (Table 2). This oomycete was isolated mostly from plants (older than seedlings) that died before the end of the assay at 45 days. Low levels of Macrophomina phaseolina were found in four samples from three different fields. Rhizoctonia solani was positive in two soil samples from two different fields.

\section{DISCUSSION}

We sought to determine the presence of different causal agents of VDs in 31 soils from 14 different fields of Guatemala where collapsed plants were observed by using two different techniques. The first technique consisted of direct isolation of fungi by plating suspensions of soil in a general agarized medium, and the other one was a bait plant method named "soil phytopathometry" previously used to isolate $F$. oxysporum f. sp. melonis from soils of Mexico (9).

Results of our investigation prove the consistent association of $O$. bornovanus and MNSV with VD in Guatemala's fields. All studied fields and $97 \%$ of all soil samples tested positive for $O$. bornovanus. MNSV also was present in all studied fields and $72 \%$ of samples, always cooccurring with the chytridiomycete.

Detection of other fungi implicated in the collapse syndrome in the same soils was lower. P. aphanidermatum was found in 20 samples representing 11 fields. $M$. phaseolina was found in five different fields. $R$. solani was isolated from only two fields. Presence of Monosporascus cannonballus was confirmed in only one of the fields. Rhizopycnis vagum and Acremonium spp. Never were isolated from the soil samples using bait plants or the soil-dilution plate technique. Moreover, samples with all these fungi also had $O$. bornovanus and MNSV.

O. bornovanus and MNSV previously were reported from Guatemala by Jordá et al. (20). This co-occurrence of fungus and virus was considered to be the main reason for the collapse of melon in Almería, Southern Spain (8) and Sardegna, Italy (34). Bruton and Miller (3) analyzed collapsed muskmelon from nine fields of Guatemala and found M. cannonballus in only one field, $R$. solani in $18 \%$ of plants, and a Stagonospora-like fungus, that might be considered $R$. vagum, in $17 \%$ of plants. To our knowledge, our study represents the first time that $P$. aphanidermatum and $M$. phaseolina are found associated with melon in Guatemala.

This work shows a technique using bait plants that allowed us to diagnose several organisms involved in VDs. The diagnosis of VD of melon is not easy due to the diversity of possible pathogens involved, and the fact that root systems of collapsed melon generally lack tertiary and feeder roots, where Olpidium must be observed (30), and remaining roots are often rotting, supplying a medium for saprophytic fungi

Table 2. Fungi isolated from roots of muskmelon grown in soil from melon production fields in Guatemala under controlled environmental conditions $\mathrm{s}^{\mathrm{a}}$

\begin{tabular}{|c|c|c|c|c|}
\hline Fungi & $\begin{array}{c}\text { Samples from } \\
\text { which fungus }^{\text {was baited }}{ }^{\mathbf{b}} \\
\end{array}$ & $\begin{array}{c}\text { Fields from } \\
\text { which fungus } \\
\text { was baited }^{\mathrm{c}}\end{array}$ & $\begin{array}{c}\text { Frequency } \\
\text { of isolation }^{\text {d }}\end{array}$ & $\begin{array}{c}\text { Frequency of } \\
\text { isolation from } \\
\text { controls (\%) }\end{array}$ \\
\hline Fusarium solani & 29 & 12 & 39.72 & 2.70 \\
\hline F. roseum ${ }^{\mathrm{e}}$ & 27 & 12 & 17.91 & 5.50 \\
\hline Paecilomyces & 26 & 13 & 30.80 & 36.30 \\
\hline F. moniliforme & 26 & 12 & 16.66 & 46.20 \\
\hline Pythium & 20 & 11 & 19.13 & 0.00 \\
\hline F. oxysporum & 20 & 9 & 5.97 & 13.7 \\
\hline Penicillium & 14 & 10 & 8.89 & 3.30 \\
\hline Cladosporium & 9 & 7 & 1.80 & 0.00 \\
\hline Aspergillus & 7 & 8 & 0.91 & 4.00 \\
\hline Curvularia & 5 & 4 & 1.44 & 0.00 \\
\hline Rhizopus & 6 & 5 & 0.81 & 4.90 \\
\hline Trichoderma & 5 & 4 & 1.97 & 0.00 \\
\hline Macrophomina phaseolina & 4 & 3 & 0.46 & 0.00 \\
\hline Mycelia sterile $^{f^{t}}$ & 3 & 2 & 0.55 & 0.00 \\
\hline Phoma & 2 & 2 & 0.33 & 0.00 \\
\hline Alternaria & 2 & 2 & 0.16 & 0.00 \\
\hline Rhizoctonia solani & 2 & 2 & 0.52 & 0.00 \\
\hline Aureobasidium & 1 & 1 & 0.32 & 0.00 \\
\hline F. dimerum & 1 & 1 & 0.11 & 0.00 \\
\hline Eріссосит & 1 & 1 & 0.06 & 0.00 \\
\hline Stemphylium & 1 & 1 & 0.05 & 0.00 \\
\hline
\end{tabular}

${ }^{a}$ Soil from each sample was diluted 1:6 with sterile vermiculite and added to a 1-liter plastic cup, where 6 seeds of the susceptible muskmelon cv. Amarillo-Canario (Ramiro Arnedo, Spain) were sown. Six replicates (glasses) per sample were randomly distributed in a climatic chamber (23 and $29^{\circ} \mathrm{C}, 16 \mathrm{~h}$ of fluorescent radiation at $12 \times 10^{3}$ lux/day) for 45 days. Three pieces of roots of each plant were plated on malt extract agar.

${ }^{b}$ From a total of 31 soil samples.

${ }^{\mathrm{c}}$ From a total of 14 fields.

${ }^{d}$ Values are the average of the frequency of isolation of 31 samples, expressed as proportion (\%) of positive plants per sample.

${ }^{\text {e }} F$. roseum was represented by $F$. equiseti ( $>90 \%$ isolates), F. semitectum, F. chlamydosporum, and $F$. acuminatum.

${ }^{\mathrm{f}}$ One of these fungi was identified later as Monosporascus cannonballus. 
that can hide the presence of VD pathogens (21). Sometimes, a few distinctive signs, such as perithecia of $M$. cannonballus on secondary and tertiary roots, or microesclerotia of Macrophomina phaseolina on the crown, may aid in the diagnosis; however, in the absence of such signs, observation of fungal sporulation on surface-sterilized tissue or isolation of the fungus in culture is needed (1). Ascospores of Monosporascus cannonballus can be recovered by a quantitative method (32) and Macrophomina phaseolina can be isolated easily from soils with soybean and maize stems (10). Carnation petals and other plant material are good traps for $P$. aphanidermatum occurring in soil or water (33). However, a general method allowing the detection from soils of all these pathogens is lacking.

The bait plant technique provided us with 45-day-old melon plants with the root system full of tertiary and feeder roots, and enough time for plants to trap the fungi and the virus. With the exception of $R$. vagum, there was at least one sample showing any of the VD pathogens. An Acremonium sp. was isolated from its positive control, and perithecia of Monosporascus cannonballus were observed on 45days-old roots belonging to three different samples. One of these samples was analyzed with bait plants by using diverse soil dilutions, and M. cannonballus's perithecia were observed on 45-day-old roots at 1:7.5 and 1:10 (wt:wt) soil:vermiculite proportion but were not observed at $1: 15$ or $1: 30$ (data not shown). This result indicates that dilution may affect diagnosis for $M$. cannonballus as an outcome of inoculum density in the analyzed soil. M. cannonballus in naturally infested soils has been reported to infect the roots from between 9 to 17 days after planting in the summer-toautumn season, and from 35 to 36 days in late winter-to-spring (31). Waugh et al. (37) reported from in vitro studies that perithecia of $M$. cannonballus were first produced between 14 and 20 days after planting, with up to 45 perithecia/ $/ \mathrm{cm}^{2}$ after 27 days at $25^{\circ} \mathrm{C}$. After 7 weeks, mature perithecia were observed on roots when melon plants were inoculated with different isolates of $M$. cannonballus (21). It also is known that $O$. bornovanus colonizes the roots of melon in less than 2 weeks, even when an infective soil was 1:100 diluted in sterile sand $(11,15)$. Macrophomina phaseolina was easily isolated from beet root seed only 4 days after inoculation and from soybean and maize stems at 15 days after inoculation (10). Garcia-Jimenez et al. isolated Acremonium spp. from roots of muskmelon 40 days after inoculation (13). For reliable detection of MNSV infection from stem tissue below the cotyledons of susceptible melon, a 40-day growth period is sufficient (23). An additional observation is the fact that melon seed can carry the MNSV. In our study, controls were positive in a similar proportion to those previously reported $(11,15)$. When MNSV was present in bait plants from soil samples, the proportion of positives was higher than controls; therefore, we could consider that seed weren't the primary inoculum source for these soils.

The another technique used, soildilution plating method, allows isolation of fungi with saprophytic activity (33). Despite regular soil disinfestation, many species of fungi were present. Some species belonged to Ascomycetae (species of Phoma, Penicillium, Paecilomyces, Aspergillus, and so on) and others to Zygomycetae (Rhizopus spp.) and Deuteromycetae. These fungi may inhibit the growth of VD pathogens on the plates. Dhingra et al. reported $M$. phaseolina to be a poorly competitive saprophyte (10) but it was the only fungus associated with VD of melon that could be isolated directly from soils. $P$. aphanidermatum, like the other VD pathogens except $M$. phaseolina, was never isolated using this soil-dilution technique but it frequently was isolated using the plant bait technique. Tello and Lacasa (33) reported similar results from Spanish soils and assumed that the soil-dilution technique favors fungal spores, not mycelium fragments, to form colonies on the agar medium. It also can be hypothesized that the time between the wetting of dried soil and plating onto the medium may be insufficient to rehydrate and activate $P y$ thium spores. Definitively, the soil-dilution technique is not a good method to isolate VD pathogens from soils, despite their known saprophytic activity.

In conclusion, the bait plant method used seems a good technique to detect the presence of different causal agents of VD, specially the obligate pathogen $O$. bornovanus and MNSV. By this technique, these two organisms consistently were associated with the presence of collapsed melon plants in Zacapa, Guatemala. To our knowledge this is the first report of such association in South America.

\section{ACKNOWLEDGMENTS}

This work was supported in part by a grant (AP20033703) from the FPU program of the Ministerio de Educación y Ciencia de España.

\section{LITERATURE CITED}

1. Aegerter, B. J., Gordon, T. R., and Davis, R. M. 2000. Occurrence and pathogenicity of fungi associated with melon root rot and vine decline in California. Plant Dis. 84:224-230.

2. Barnett H. L., and Hunter, B. B. 1972. Illustrated Genera of Imperfecti Fungi, 4th ed. Macmillan Publishing Company, New York.

3. Bruton, B. D., and Miller, M. E. 1997. Ocurrence of vine decline diseases of muskmelon in Guatemala. Plant Dis. 81(6):694.

4. Bruton, B. D., and Miller, M. E. 1997. Occurrence of vine decline diseases of melons in Honduras. Plant Dis. 81:696.

5. Carter, W. W. 1979. Importance of Macrophomina phaseolina in vine decline and fruit rot of cantaloupe in South Texas. Plant Dis. Rep. 63:927-930.
6. Cebolla, V., Cangos, T., and García, M. 1990. Rhizoctonia solani: causante del colapso del melón en el País Valenciano. Actas de Horticultura del III Congreso Nacional de Ciencias Hortícolas.

7. Champaco, E. R., Martyn, R. D., Barnes, L. W., Miller, M. E., Amador, J. M., and Perez, A. 1988. Root rot, a new disease of muskmelon in South Texas. (Abstr.). Phytopathology 78:626.

8. Cuadrado, I. M., Gómez, J., and Moreno, P. 1993. El virus de las manchas necróticas del melón (MNSV) en Almería. I. Importancia del MNSV como causa de la muerte súbita del melón. Bol. San. Veg. Plagas 19:93-106.

9. De Cara, M., Diánez, F., Santos, M., Estrada, F. J., Montoya, S., Fernández, E. J., and Tello, J. C. 2006. Presence of Fusarium oxysporum f. sp. melonis race 1 in soils cultivated with melon in the State of Colima (Mexico). Geomicrobiol. J. Vol. 23:319-322.

10. Dhingra, O. D., Tenne, F. D., and Sinclair, J. B. 1976. Method for determination of competitive saprophytic colonization of soil fungi. Trans. Br. Mycol. Soc. 66:447-456.

11. Dias, H. F. 1970. Transmission of cucumber necrosis virus by Olpidium cucurbitacearum Barr \& Dias. Virology 40:828-839.

12. Farr, D. F., Miller, M. E., and Bruton, B. D. 1998. Rhizopycnis vagum gen. et sp. nov., a new coelomycetous fungus from roots of melons and sugarcane. Mycologia 90(2):290-296.

13. García-Jiménez, J., Velázquez, M. T., Jordá, C., and Alfaro-García, A. 1994. Acremonium species as the causal agent of muskmelon collapse in Spain. Plant Dis. 78(4):416-419.

14. Gerik, J. S. 1992. Zoosporic obligate parasites of roots. Pages 18-24 in: Methods for Research on Soilborne Phytopathogenic Fungi. L. L. Singleton, J. D. Mihail, and C. M. Rush, eds. American Phytopathological Society Press, St. Paul, MN.

15. Gómez Vázquez, J. 2003. Enfermedades del Melón y Pepino en los Cultivos sin Suelo del Sudeste Andaluz. Ph.D. dissertation, Universidad de Almería, Spain.

16. Gotlieb, M., and Butler, K. D. 1939. A Pythium root rot on cucurbits. Phytopathology 29(7):624-628.

17. Gubler, W. D., and Grogan, R. E. 1982. Factors affecting sudden wilt of melon in California. (Abstr.) Phytopathology 72:986.

18. Hanlin T. T. 1990. Illustrated Genera of Ascomycetes, Vol. I. The American Phytopathological Society Press, St. Paul, MN.

19. Hanlin T. T. 1992. Illustrated Genera of Ascomycetes, Vol. II. The American Phytopathological Society Press, St. Paul, MN

20. Jordá, C., Font, M. I., Martinez-Culebras, P., and Tello, J. 2005. Viral etiology of diseases detected in melon in Guatemala. Plant Dis. 89(3):338.

21. Lovic B. R. 1994. Molecular studies of Monosporascus spp.: applications in diagnostics, taxonomy, population biology, and control. Ph.D. dissertation, Texas A \& M University, College Station.

22. Lovic, B. R., Martyn, R. D., and Miller, M. E. 1995. Sequence analysis of the ITS regions of DNA in Monosporascus spp. to evaluate its potential for PCR-mediated detection. Phytopathology 85:655-661.

23. Mallor, C., Luis-Arteaga, M., Alvarez, J. M. Montaner, C., and Floris, E. 2006. Resistance to Melon necrotic spot virus in Cucumis melo L. 'Doublon' artificially inoculated by the fungus vector Olpidium bornovanus. Crop Prot. 25(5):426-431.

24. Martin, R. D., and Miller, M. E. 1996. Monosporascus root rot and vine decline: an emerging disease of melons worldwide. Plant Dis. 80(7):716-725

25. Merteley, J. C., Martyn, R. D., Miller, M. E., and Bruton, B. D. 1991. Role of Monosporas- 
cus cannonballus and other fungi in a root rot/vine decline disease of muskmelon. Plant Dis. 75:1133-1137.

26. Miller, M. E., Bruton, B. D., and Farr, D. F. 1996. Rhizopycnis cucumeris, a recently described soilborne pathogen on cucurbits. Pages 33-39 in: Melon Production Systems in South Texas. M. E. Miller, B. Bruton, L. Brandenberger, J. Batten, D. F. Farr, C. Lander, G. Lester, R. Martyn, E. T. Mirkov, Y. J. Park, R. Wiedenfeld, and D. Wolff, eds. Texas Agric. Ext. Serv. Annu. Rep.

27. Nelson, E., Toussoun, T. A., and Marasas, W. F. O. 1983. Fusarium Species. An Illustrated Manual for Identification. The Pennsylvania State University Press.

28. Pivonia, S., Cohen, R., Kafkafi, U., Ben Ze'ev, I. S., and Katan, J. 1997. Sudden wilt of melons in southern Israel: fungal agents and relationship with plant development. Plant Dis.
81(11):1264-1268.

29. Reuveni, R., Krikun, J., and Shani, U. 1983. The role of Monosporascus eutypoides in a collapse of melon plants in an arid area of Israel. Phytopathology 73:1223-1226.

30. Schwartz, E. J., and Cook, W. E. I. 1928. The life-history and cytology of a new species of Olpidium; Olpidium radicale sp. nov. Trans. Br. Mycol. Soc. 13(3-4):205-221.

31. Stanghellini, M., Kim, D. H., Waugh, M. M., Ferrin, D. M., Alcantara, T., and Rasmussen, S. L. 2004. Infection and colonization of melon roots by Monosporascus cannonballus in two cropping seasons in Arizona and California. Plant Pathol. 53:54-57.

32. Stanghellini, M. E., and Rasmussen, S. L. 1992. A quantitative method for the recovery of ascospores of Monosporascus cannonballus from field soil. (Abstr.) Phytopathology $82: 1115$.
33. Tello Marquina, J. C., and Lacasa Plasencia, A 1990. Fusarium oxysporum en los Cultivos Intensivos del Litoral Mediterráneo de España: Fases Parasitaria (Fusariosis Vasculares del Tomate y del Clavel) y No Parasitaria. Ministerio de Agricultura Pesca y Alimentación, Secretaría General Técnica, Madrid.

34. Tomassoli, L., and Barba, M., 2000. Occurrence of melon necrotic spot carmovirus in Italy. Bull. OEPP 30(2):279-280.

35. Troutman, J. L., and Matejka, J. C. 1970. Three fungi associated with cantaloupe roots in Arizona. Phytopathology 60(9):1317.

36. Van der Plaats-Niterink, A. J. 1981. Monograph of the genus Pythium. Stud. Mycol. 21:1-242.

37. Waugh, M. M., Kim, D. H., Ferrin, D. M., and Stanghellini, M. E. 2003. Reproductive potential of Monosporascus cannonballus. Plant Dis. 87:45-50. 